\title{
CodinGame sebagai Alat Bantu Latihan Pemrograman Berbasis Penyelesaian Tantangan
}

\author{
Muhammad Rizqi Sholahuddin ${ }^{1}$, Firas Atqiya ${ }^{2}$ \\ 1) Jurusan Teknik Komputer dan Informatika, Politeknik Negeri Bandung \\ Jl. Gegerkalong Hilir, Ciwaruga, Kec. Parongpong, Kabupaten Bandung Barat, Jawa Barat 40559 \\ Email: muhammad.rizqi@polban.ac.id \\ 2) Prodi Teknik Informatika, Fakultas Sains dan Teknologi, Universitas Muhammadiyah Bandung \\ Jl. Soekarno-Hatta No.752, Cipadung Kidul, Kec. Panyileukan, Kota Bandung, Jawa Barat 40614 \\ Email: firasatqiya@umbandung.ac.id
}

\begin{abstract}
ABSTRAK
Pemrograman adalah salah satu keterampilan yang harus sering dilatih di kalangan mahasiswa bidang ilmu komputer dan sejenisnya. Paper ini akan membahas mengenai penggunaan CodinGame sebagai alat bantu berlatih pemrograman. CodinGame merupakan platform dengan model game-based programming: Platform ini dibekali banyak fitur yang mendukung penggunanya untuk dapat berlatih secara mandiri. Terdapat banyak tantangan yang dapat dipilih pengguna untuk berlatih pemrograman. Hasil evaluasi menunjukkan bahwa pengguna merasa tertarik dan termotivasi untuk menggunakan platform CodinGame. Selain itu, pengguna juga merasa terbantu dalam berlatih pemrograman di platform ini sehingga pengguna merasa lebih termotivasi untuk berlatih pemrograman.
\end{abstract}

Kata kunci: CodinGame, pemrograman, tantangan, game

\begin{abstract}
In this paper, we discuss CodinGame as a tool to help students in computer science departments learn programming. Programming is a crucial ability for those aiming to be a programmer. As a result, students must practice programming on a frequent basis. CodinGame is a programming platform that uses a game-based model. It has a lot of self-practice features. Users can select from a variety of challenges for practice programming. Users were interested in and motivated to use the CodinGame platform, according to the results. Therefore, users find it helpful to practice programming on this platform in order to feel more motivated to do so.
\end{abstract}

Keywords: CodinGame, programming, challenge, game

\section{Pendahuluan}

Pemrograman merupakan hal wajib yang harus dikuasai oleh mahasiswa bidang ilmu komputer atau informatika. Mahasiswa dituntut untuk dapat menyelesaikan berbagai masalah dalam pemrograman, yang dalam prosesnya membutuhkan kemampuan analisis dan logika [1]. Analisis dan logika erat kaitannya dengan kemampuan matematika seseorang. Mengenalkan konsep dasar pemrograman kepada mahasiswa baru yang belum memiliki pengetahuan sama sekali mengenai programming merupakan hal yang tidak mudah [2]. Sebagai contoh materi konsep percabangan dan perulangan merupakan materi yang membutuhkan analisis dan logika tinggi, serta konsep tersebut akan terus digunakan bahkan hingga di dunia kerja profesional. Konsep percabangan dan perulangan terlihat sederhana bagi yang sudah berpengalaman. Namun bagi yang baru mengenal konsep percabangan dan perulangan, hal tersebut dirasa cukup abstrak dan membingungkan sehingga diperlukan visualisasi dari konsep tersebut. Dengan bantuan visualisasi diharapkan mahasiswa menjadi tertarik dan lebih mudah memahami konsep tersebut.

Berdasarkan [3] aplikasi komputer edukasional menunjukkan efektivitas dalam meningkatkan pemahaman seseorang dalam mempelajari konsep matematika. Pada saat ini terdapat banyak aplikasi berbasis online yang dimanfaatkan sebagai media pembelajaran, misalnya saja Dragonbox Algebra 5+ yang dapat digunakan sebagai media pembelajaran aljabar [4] dan Geogebra yang digunakan digunakan sebagai alat bantu pembelajaran geometri [5]. Aplikasi berbasis online yang dapat membantu proses pembelajaran pemrograman juga ada banyak. Pada paper ini akan dibahas mengenai aplikasi online pembelajaran pemrograman dengan model game-based programming. Platform yang menyediakan pembelajaran dengan model ini diantaranya adalah Getcoding, CodeMonkey, Kodable, Rapid Router dan CodinGame. Konsep pemrograman yang dibuat 
menjadi pembelajaran interaktif pada platform tersebut cukup lengkap [6] dan juga disertai dengan gamifikasi untuk pengguna.

Paper ini akan membahas implementasi dan contoh kasus yang tersedia pada CodinGame. Peneliti memilih CodinGame karena platform tersebut menyediakan fasilitas auto-assessment, forum, ruang obrolan dan challenge yang cocok bagi pembelajaran di tingkat pendidikan tinggi.

\section{Metode Penelitian}

Metode yang digunakan dalam penelitian ini adalah dengan studi literatur, observasi langsung terhadap platform CodinGame dan menyebarkan kuesioner kepada mahasiswa yang sudah menggunakan fitur practice. Studi literatur bersumber dari berbagai jurnal dan artikel daring yang digunakan sebagai referensi terkait pembelajaran pemrograman yang memanfaatkan model game-based programming. Peneliti juga melakukan observasi terkait fitur-fitur pada CodinGame. Fitur terkait pembelajaran pada CodinGame terdapat pada menu activities yang terdiri dari practice, compete, dan learn. Hal yang ditinjau lebih dalam pada penelitian ini adalah kegunaan fitur practice.

Peneliti melakukan evaluasi kepada mahasiswa yang sebelumnya diminta untuk mengerjakan latihan di CodinGame. Evaluasi dilakukan dengan menggunakan User Experience Questionnaire (UEQ) dan beberapa pertanyaan tambahan tentang pengalaman berlatih pemrograman di CodinGame.

\section{CodinGame}

CodinGame (https://www.codingame.com) adalah sebuah platform berbasis web yang ditujukan untuk melatih kemampuan pemrograman [7] dengan cara menyediakan permasalahan yang menantang bagi penggunannya. Pengguna akan diminta untuk menyelesaikan permasalahan tersebut dengan menuliskan kode solusi menggunakan bahasa pemrograman yang mereka kuasai. CodinGame memfasilitasi 27 bahasa pemrograman, di antaranya C, C++, Java, JavaScript, Kotlin, Phyton, Swift, dll.

CodinGame menerapkan model game-based programming. Dengan model demikian setiap kodingan yang ditulis pengguna akan langsung berpengaruh kepada lingkungan game. Pengguna memiliki tugas untuk memodifikasi kode sehingga game berjalan sesuai goal dari tantangan. Setiap baris kode yang ditulis oleh pengguna efeknya langsung terlihat pada visualisasi game. Hal ini memberi kesempatan kepada pengguna untuk mengamati langsung pengaruh tiap baris kode yang ditulisnya terhadap lingkungan game.

Gambar 1 menunjukkan bahwa terdapat tiga fitur utama yang tampil di bagian menu bar, yaitu activity, community, dan get a job. Pada fitur get a job, pengguna dapat mengisikan data terkait kriteria pekerjaan yang diinginkan sehingga jika pihak CodinGame menemukan kecocokan kriteria antara pengguna dan perusahaan yang ada dalam jaringannya, maka kedua pihak akan dihubungkan oleh CodinGame. Pada fitur community, pengguna difasilitasi untuk dapat berinteraksi dengan pengguna lainnya, baik itu melalui forum, ruang obrolan, ataupun livestream. Pada fitur activity, pengguna dapat memilih beberapa aktivitas seperti practice, compete, cooperate, atau learn.

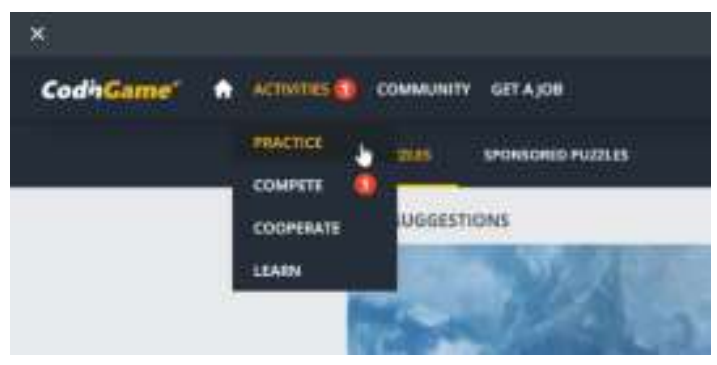

(https://www.codingame.com)

Gambar 1. Tampilan pilihan fitur activity yang terdapat pada CodinGame

\section{Fitur activity practice}

Gambar 2 menunjukan bahwa pada fitur activity practice, CodinGame menyediakan tantangan koding yang dapat dipilih tingkat kesulitannya, dimulai dari level easy, medium, hard, hingga very hard. Setiap level 
menyediakan pilihan tema tantangan berdasarkan konsep pemrograman. Ada tantangan yang hanya menerapkan satu konsep pemrograman saja, misalnya power of thor, tantangan yang memerlukan pemahaman konsep percabangan untuk menyelesaikannya. Ada pula tantangan yang menerapkan kombinasi beberapa konsep sekaligus, misalnya temperatures, tantangan yang memerlukan pemahaman konsep array, perulangan dan percabangan.

Pengguna diharuskan mengembangkan software agent (SA) untuk dapat menyelesaikan setiap tantangan yang dipilih [7]. SA merupakan program komputer yang bertindak untuk pengguna atau program lain dalam hubungan keagenan [8]. SA yang terdapat pada CodinGame berperan sebagai visualisasi karakter game pada tantangan atau permainan yang dipilih. Karakter akan bergerak otomatis sesuai dengan instruksi koding yang dituliskan oleh pengguna pada editor code yang sudah disediakan.

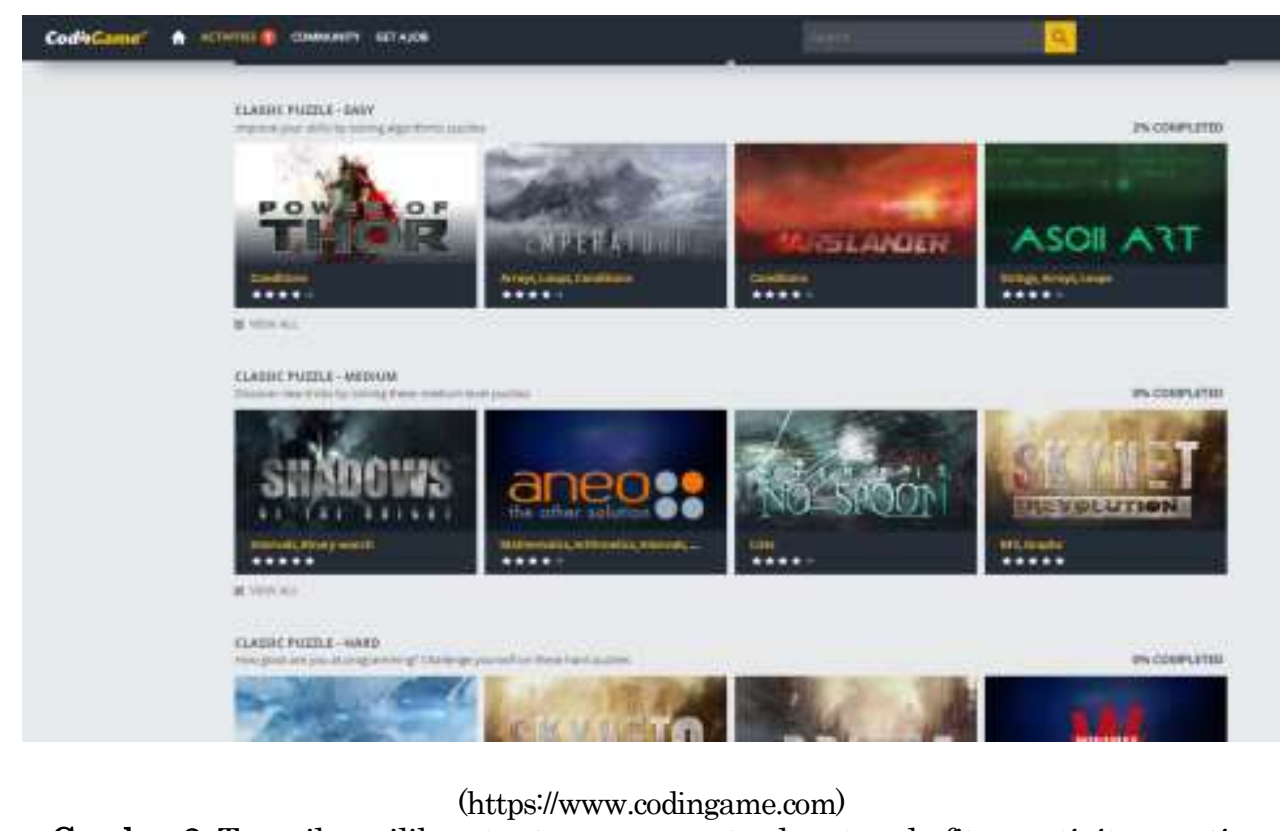

Gambar 2. Tampilan pilihan tantangan yang terdapat pada fitur activity practice

Tampilan permainan pada CodinGame mengintegrasikan antara code editor tradisional dengan visualisasi game-like [9] seperti yang terlihat pada Gambar 3.

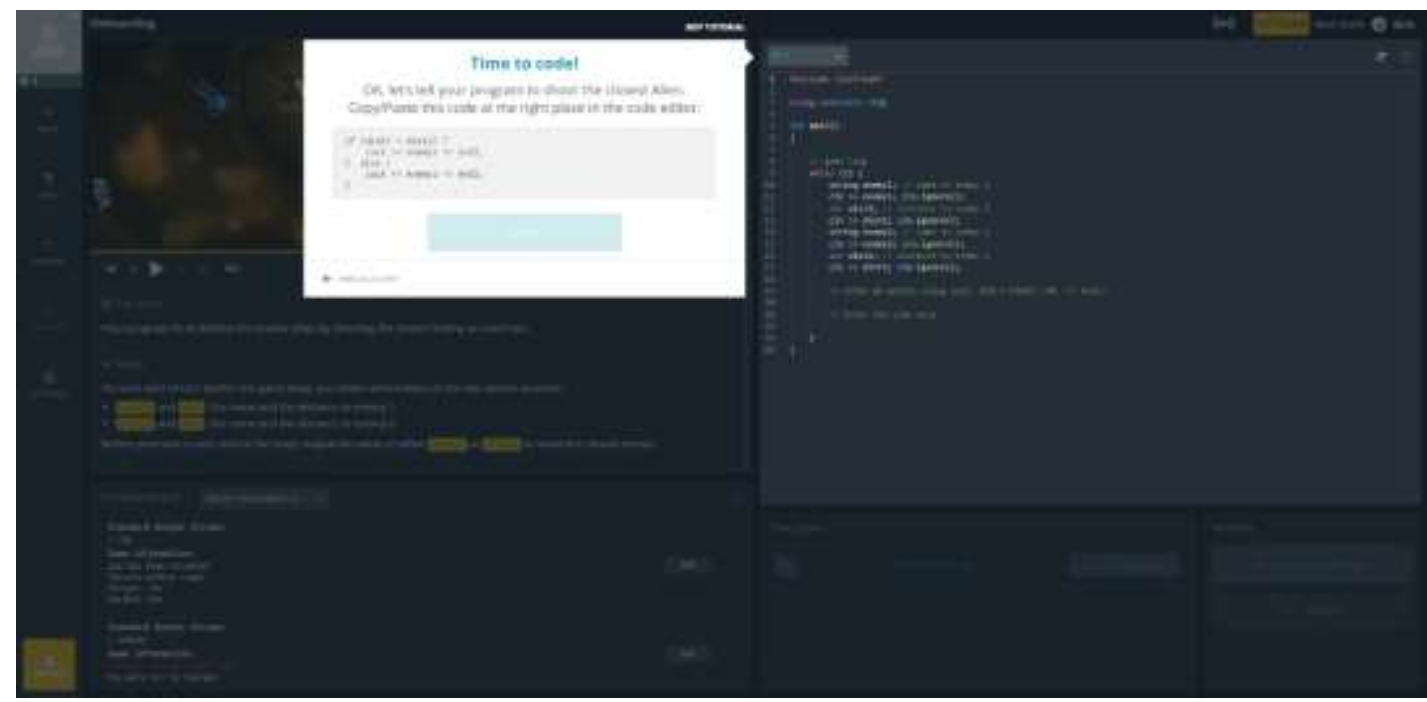

(https://www.codingame.com)

Gambar 3. Tampilan awal salah satu permainan pada CodinGame 
Tampilan muka pada CodinGame terbagi menjadi beberapa bagian, diantaranya adalah code editor, visualisasi game, tujuan dan instruksi permainan, console output, test cases, dan bagian aksi pengguna.

Code editor adalah tempat di mana pengguna memodifikasi kode awal yang diberikan. Pengguna dapat memilih bahasa pemrograman yang sesuai dengan kebutuhan mereka. Pada code editor pengguna harus menuliskan kode yang sesuai dengan instruksi permainan sehingga tujuan permainan dicapai.

Visualisasi game adalah tampilan di mana karakter akan bergerak sesuai dengan kode yang dituliskan pada code editor. Apapun baris kode yang dituliskan pengguna akan berpengaruh pada visualisasi game. Jika pengguna belum menuliskan kode yang sesuai, notifikasi error akan terlihat pada visualisasi gamedan console seperti yang terlihat pada Gambar 4.

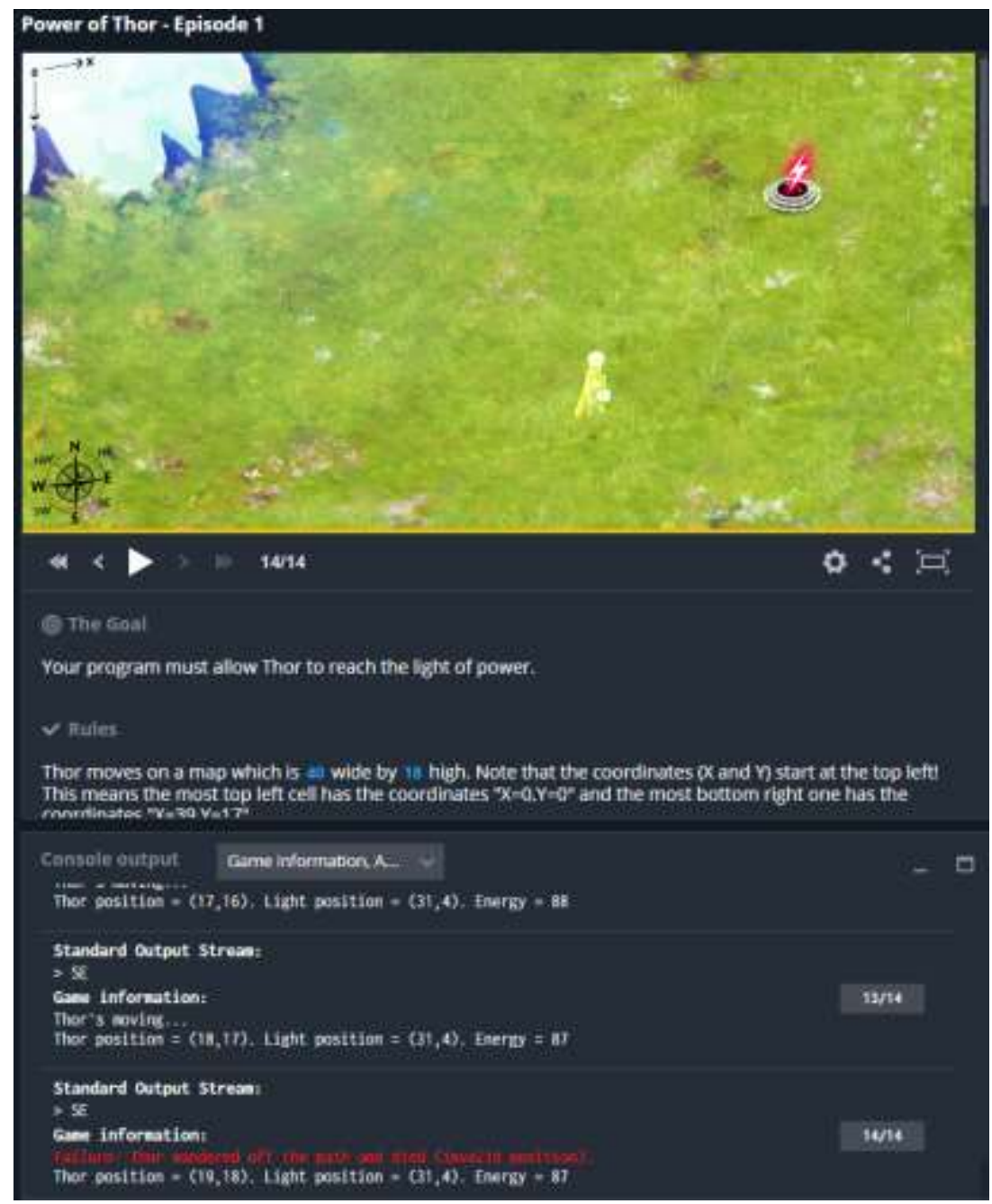

(https://www.codingame.com)

Gambar 4. Tampilan gagal salah satu permainan pada CodinGame

Test cases berguna untuk memeriksa apakah kode yang dituliskan pada code editor dapat mencapai tujuan permainan atau tidak. Test case akan berubah menjadi warna merah jika gagal dan akan berubah menjadi warna hijau jika berhasil. Setiap tantangan memiliki beberapa test cases. Pengguna dituntut membuat sebuah solusi yang dapat memenuhi seluruh test casesyang tersedia. Jika salah satu test cases tidak terpenuhi maka solusi dianggap gagal. Sebaliknya jika seluruh test cases terpenuhi berarti tujuan permainan sudah dicapai dan pengguna dapat menekan tombol submit yang ada pada bagian actions (aksi pengguna) seperti pada Gambar 5. 


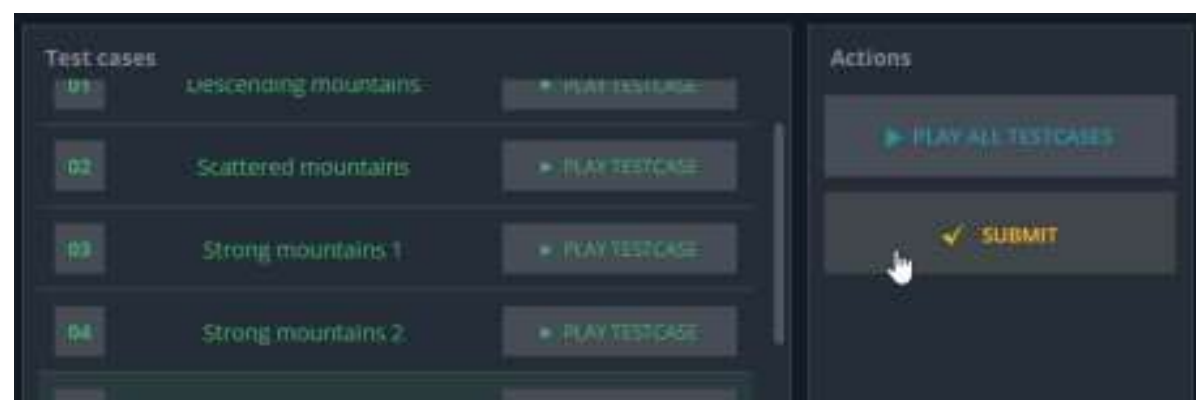

(https://www.codingame.com)

Gambar 5. Tampilan test cases dan actions

\section{Fitur activity compete}

Fitur compete bertujuan meningkatkan efisiensi pemrograman seseorang. Pengguna akan berkompetisi dengan pengguna lainnya untuk menyelesaikan masalah pemrograman sederhana dalam waktu yang telah ditentukan. Pada fitur ini pengguna akan ditantang untuk memahami permasalahan dan memberikan solusi permasalahan dalam waktu singkat. Kondisi tersebut membuat keterampilan pengguna dalam memecahkan masalah akan terasah. Di akhir sesi kompetisi, pengguna dapat membagikan solusi yang sudah dibuat untuk membantu pemain lain.

Gambar 6 merupakan tampilan ketika pengguna sudah menyelesaikan kompetisi. Score dan durasi pengerjaan dari seluruh pengguna yang ikut serta dalam kompetisi akan ditampilkan pada halaman tersebut.

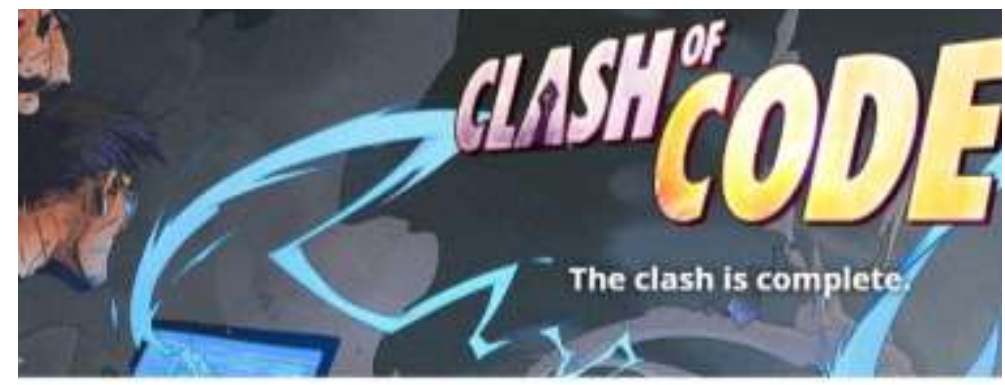

uesutis

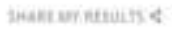

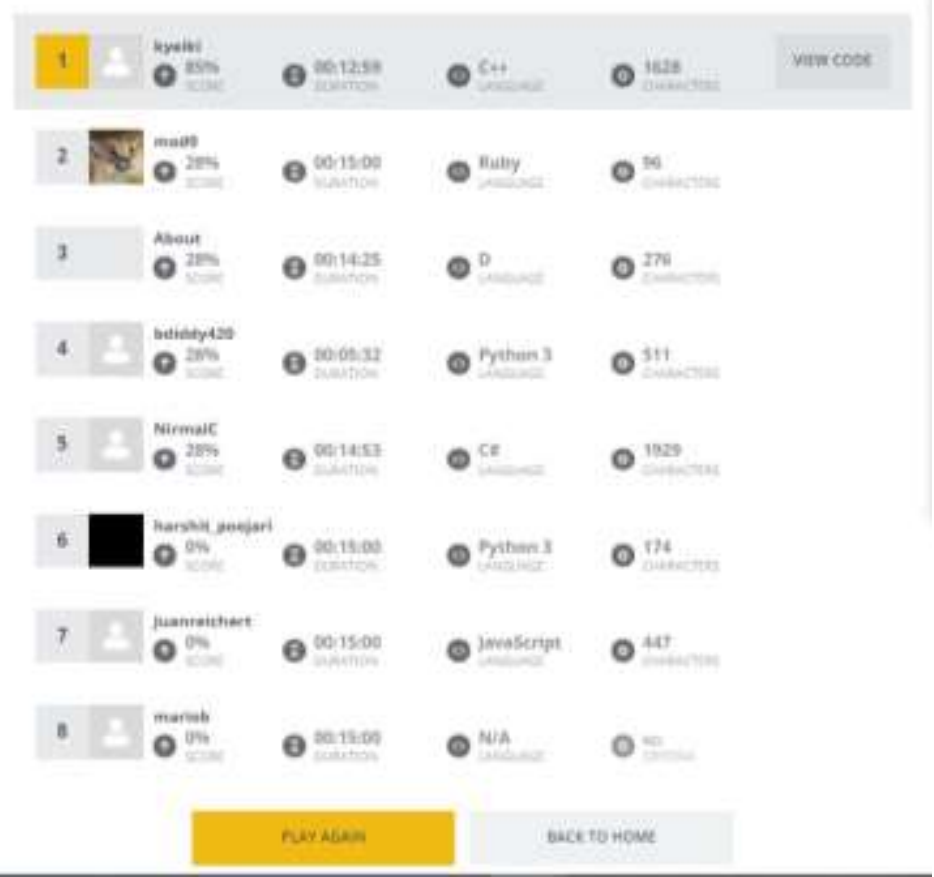


(https://www.codingame.com)

Gambar 6. Tampilan akhir dari fitur compete

\section{Fitur activity learn}

Fitur activity learn berisikan berbagai materi pembelajaran yang dituliskan oleh sesama pengguna. Pembelajaran dapat berupa penjelasan teori, latihan memperbaiki kode maupun tes konsep pemrograman.

\section{Hasil Penelitian}

\section{Hasil observasi CodinGame}

Pengguna harus membuat akun terlebih dahulu pada platform CodinGame untuk dapat mengakses berbagai fitur yang tersedia. Setelah memiliki akun, pengguna dapat memilih fitur activity practice untuk mencoba berbagai tantangan yang disediakan. Tingkat kesulitan tantangan terdiri dari level easy, medium, hard, dan very hard. Setiap level tantangan terdiri dari berbagai tema konsep pemrograman, seperti percabangan, perulangan, array, string, dan lainnya.

Tantangan yang akan dibahas pada paper ini adalah tantangan yang menerapkan salah satu konsep pemrograman, yaitu percabangan. Tantangan yang terkait dengan percabangan ada banyak, di antaranya adalah Power of Thor, The Last Crusade, Don't Panic, dan Texas Holdem seperti yang terlihat pada Gambar 7. Peneliti akan meninjau salah satu dari tantangan yang ada. Tantangan yang dipilih adalah Power of Thor.
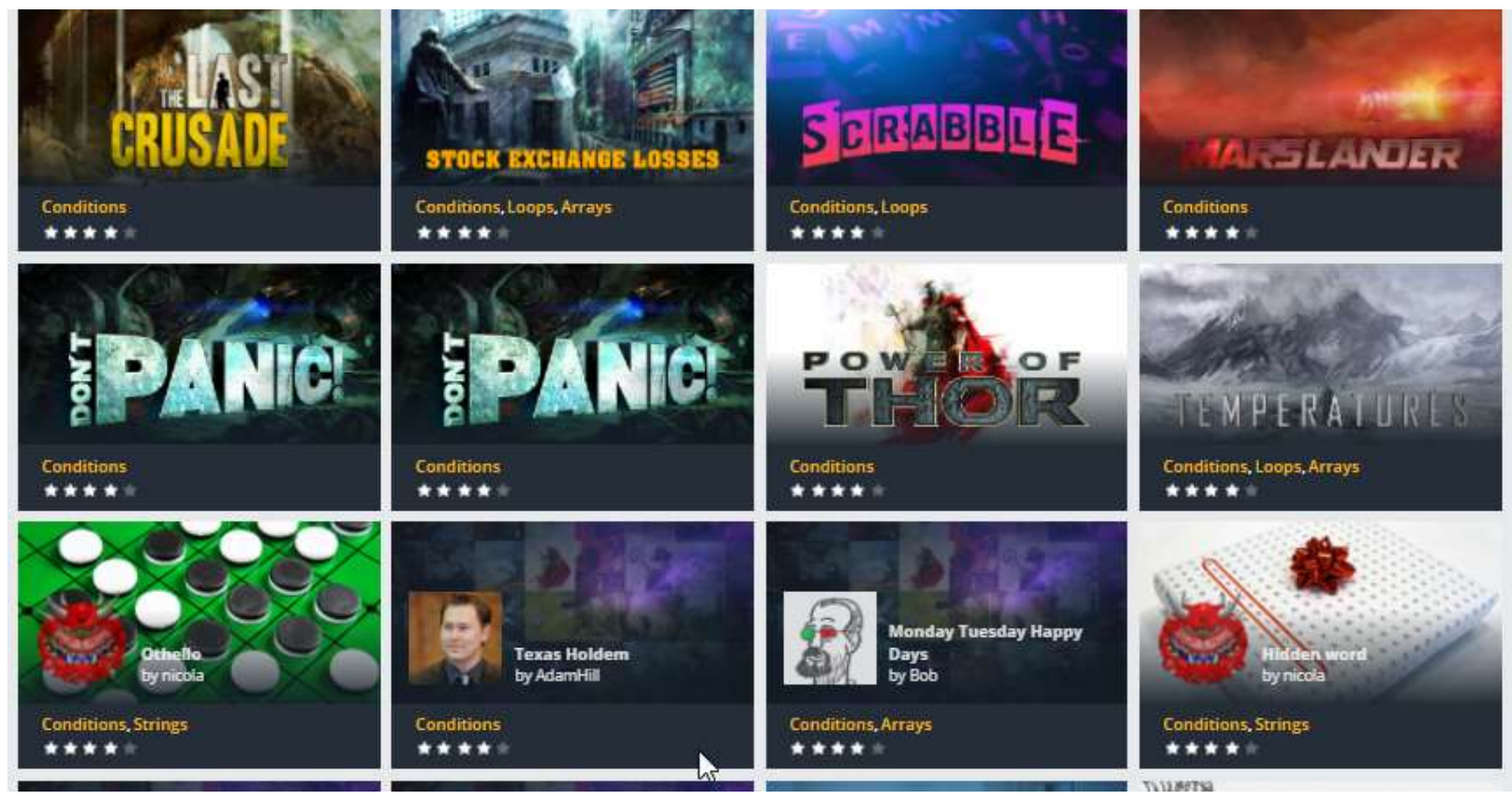

(https://www.codingame.com)

Gambar 7. Pilihan tantangan yang terkait dengan konsep percabangan 


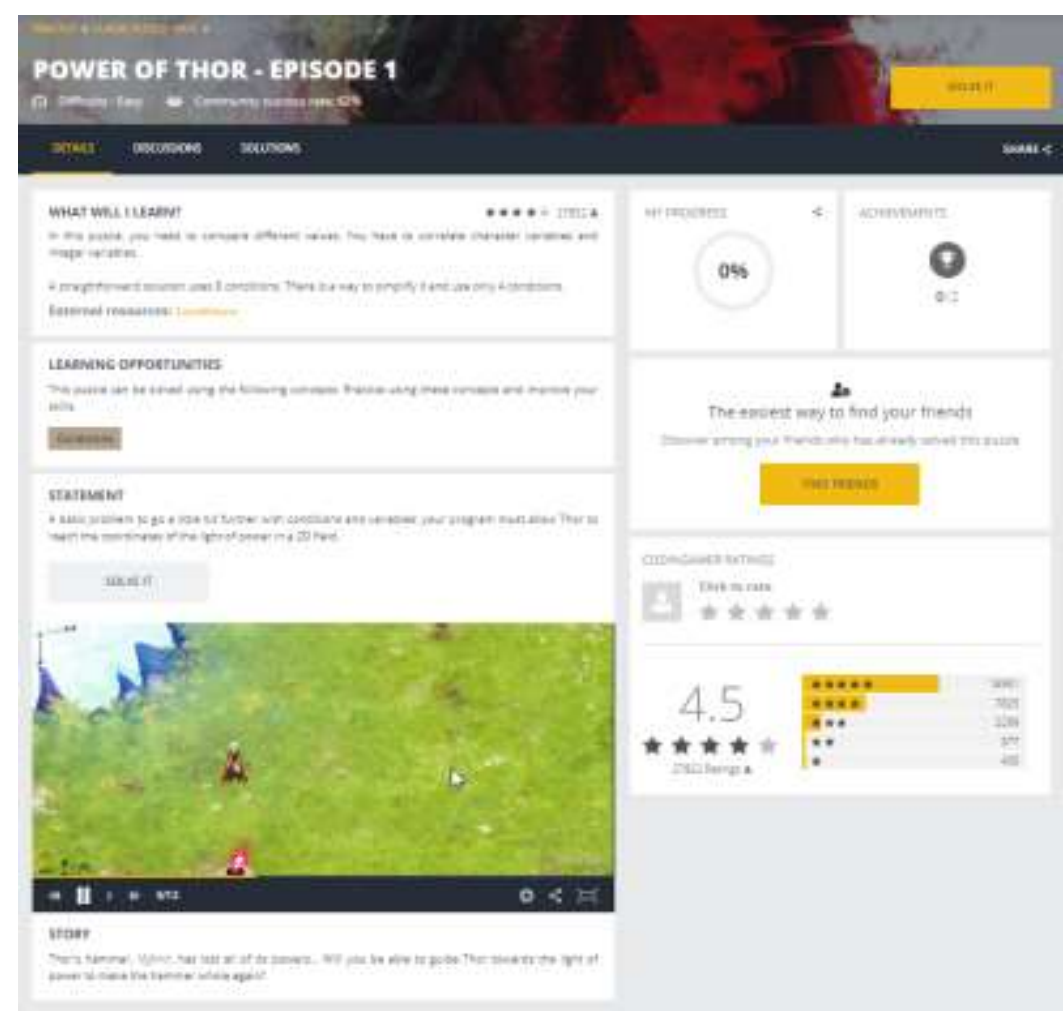

(https://www.codingame.com)

Gambar 8. Tampilan halaman detail tantangan Power of Thor- Episode 1

Gambar 8 adalah tampilan detail dari tantangan yang berjudul Power of Thor - episode 1. Pada halaman tersebut ditampilkan berbagai informasi, seperti mengenai apa yang akan dipelajari (what will I learn?), konsep materi terkait tantangan (learning opportunity), statement, alur cerita dari tantangan (story), serta informasi mengenai pengguna (my progress dan achievements). Ketika pengguna menekan tombol solve it, tampilan muka seperti pada Gambar 9 akan muncul.

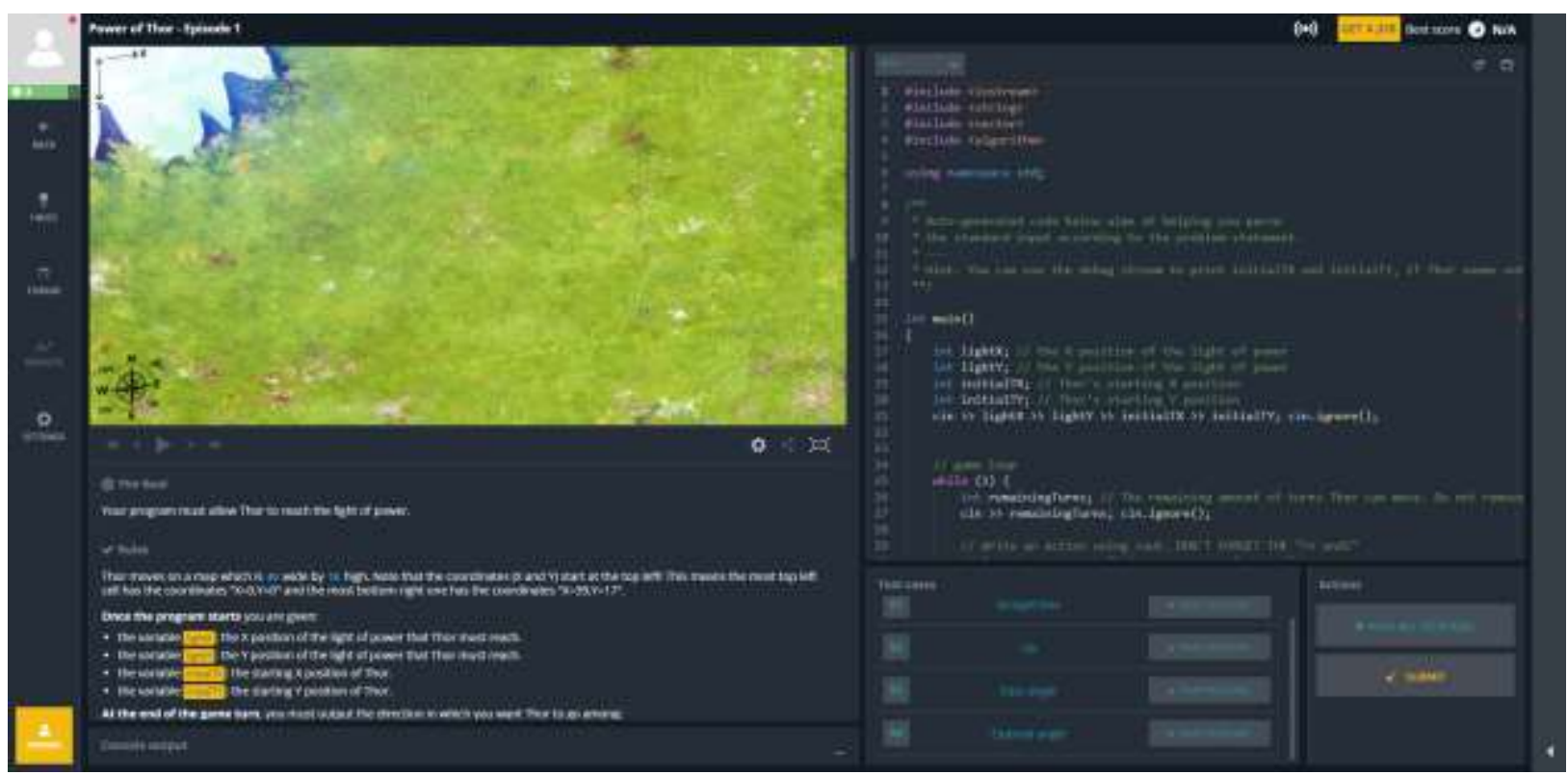

(https://www.codingame.com)

Gambar 9. Tampilan halaman detail tantangan Power of Thor- Episode 1 
Tujuan dari tantangan Power of Thor adalah menuliskan baris-baris kode yang akan menggerakkan karakter Thor menuju koordinat tujuan, yaitu the light of power.

Aturan yang diberikan adalah sebagai berikut:

1. Thor bergerak pada peta 2 dimensi dengan ukuran lebar 40 dan panjang 18 . Titik awal koordinat $(0,0)$ berada pada posisi pojok kiri atas, yang berarti posisi pojok kanan bawah berkoordinat $(39,17)$.

2. Pengguna diberikan koordinat tujuan dan koordinat awal posisi karakter Thor.

3. Pengguna memiliki batasan jumlah gerak atau langkah.

4. Untuk membuat Thor bergerak pengguna harus mencetak huruf pertama 8 arah mata angin dalam bahasa inggris, seperti $\mathrm{W}$ untuk barat, E untuk timur, N untuk utara, S untuk selatan, dll.

5. Thor tidak boleh melewati batas map.

Power of Thor memiliki empat buah test cases. Setiap test case memiliki koordinat awal yang berbeda, baik itu untuk posisi karakter thor maupun posisi tujuan (light of power). Detail perbandingan koordinat awal dari keempat test cases disajikan pada Tabel 1.

Tabel 1. Perbandingan koordinat awal untuk setiap test cases

\begin{tabular}{|c|c|c|}
\hline Nama Test Cases & Koordinat Awal Thor & Koordinat Light Of Power \\
\hline Straight line & $(5,4)$ & $(31,4)$ \\
\hline Up & $(31,17)$ & $(31,4)$ \\
\hline Easy angle & $(31,4)$ & $(0,17)$ \\
\hline Optimal angle & $(0,0)$ & $(36,17)$ \\
\hline
\end{tabular}

Kode awal yang diberikan oleh CodinGame terlihat pada Gambar 10. Pengguna harus bisa mengembangkan kode tersebut dengan menambahkan beberapa baris kode sehingga semua test cases berubah menjadi warna hijau yang berarti tujuan telah tercapai.

CodinGame menyediakan menu bantuan berupa hint bagi pengguna yang mengalami kesulitan dalam menyelesaikan tantangan. Posisi menu hint ada di sebelah kiri, di bawah tombol back (lihat Gambar 9). Menu hint ini terdiri dari lima level bantuan, yang pada dua level bantuan terakhir hint berupa pseudocode dan solusi dari tantangan. Menu hint secara lengkap ditampilkan pada Gambar 11. 


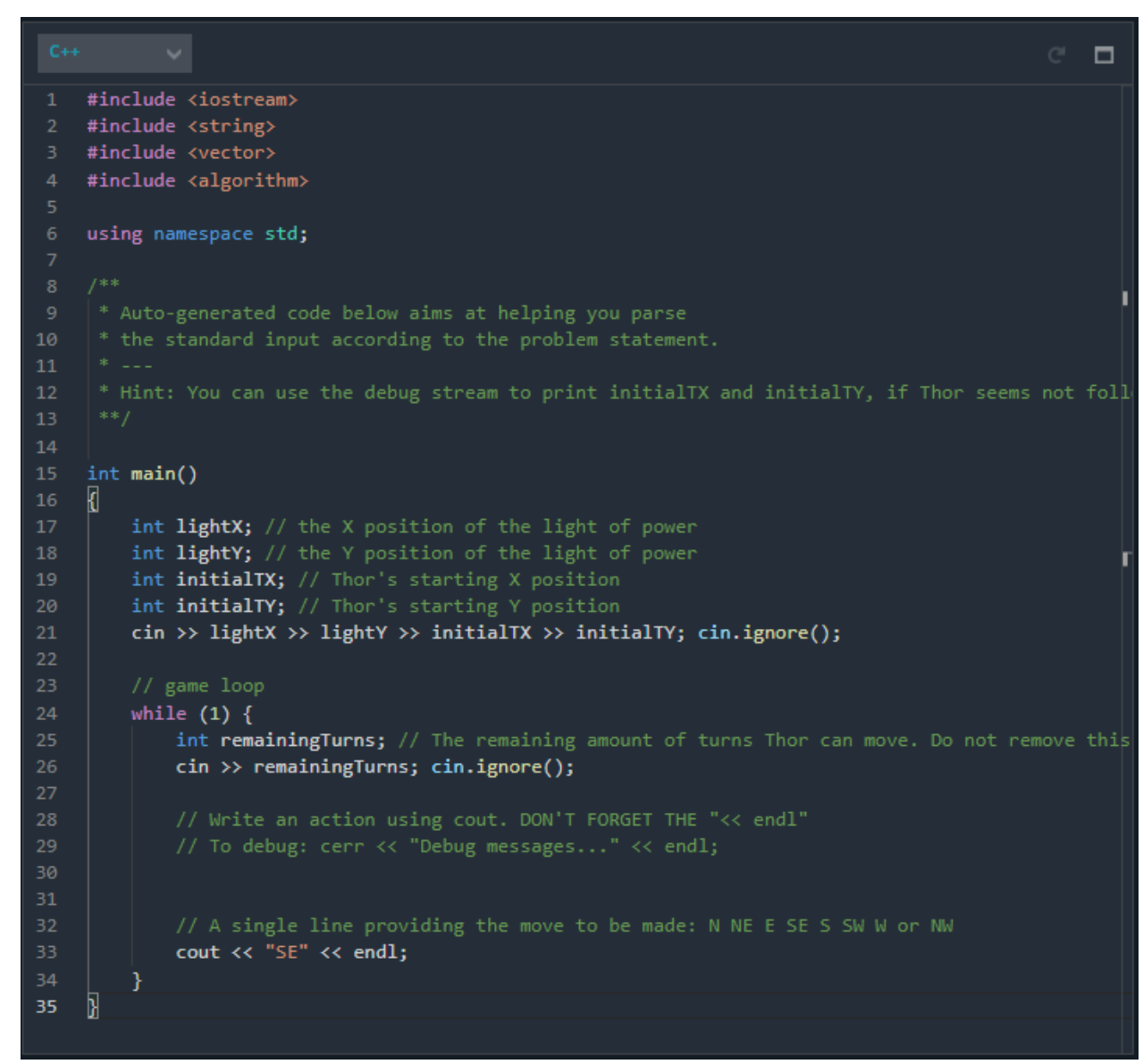

(https://www.codingame.com)

Gambar 10. Tampilan halaman detail tantangan Power of Thor- Episode 1

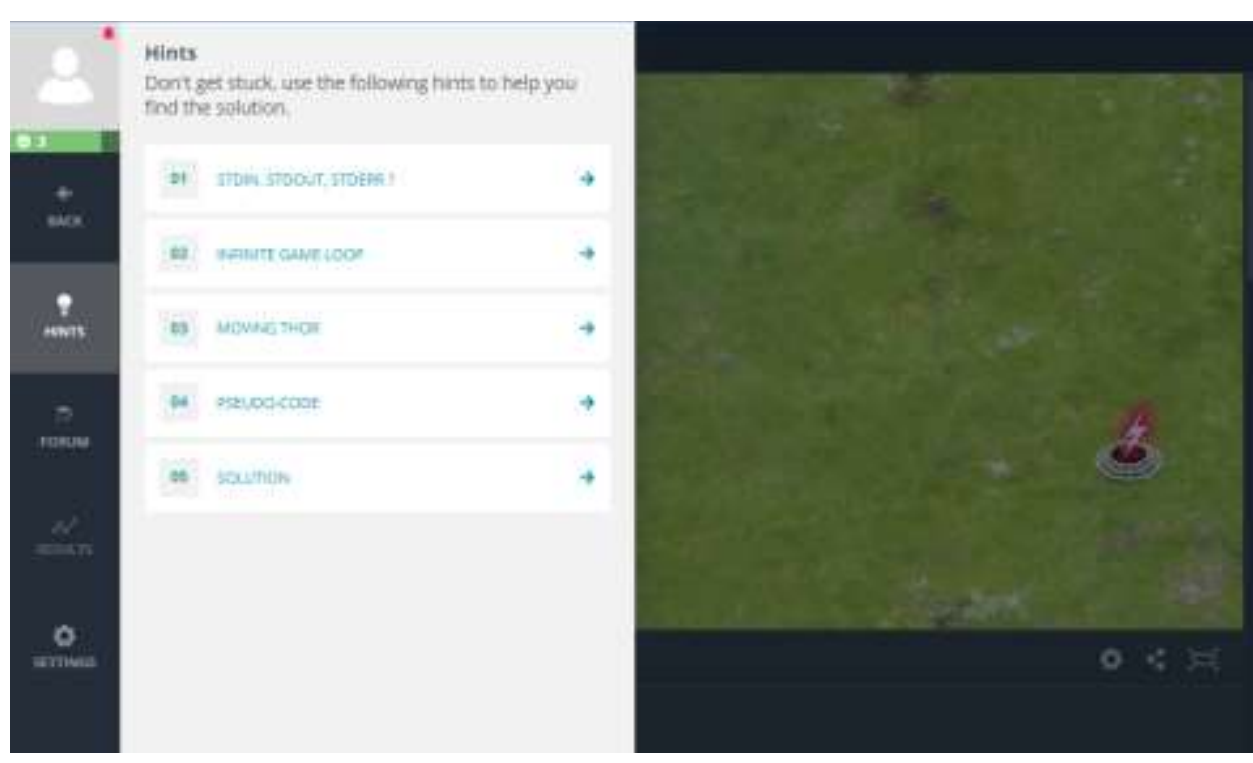

(https://www.codingame.com)

Gambar 11. Hint yang tersedia pada tantangan

Apabila pengguna sudah memodifikasi kode awal (pada Gambar 10) dan dengan kode hasil modifikasi tersebut mengubah warna semua test cases menjadi warna hijau seperti pada Gambar 12, maka baris kode tersebut merupakan solusi dari tantangan Power of Thor. Langkah selanjutnya adalah menekan tombol submit, kemudian akan muncul tampilan seperti pada Gambar 13. 


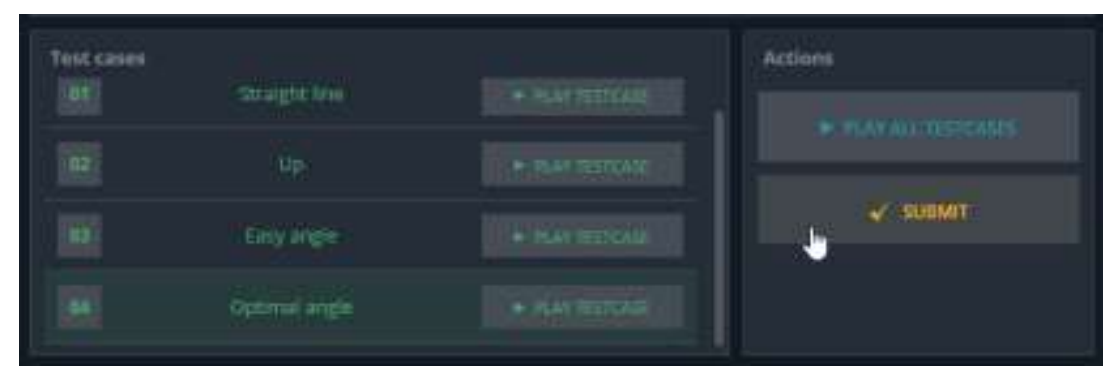

(https://www.codingame.com)

Gambar 12. Test cases Power of Thor yang telah dipenuhi

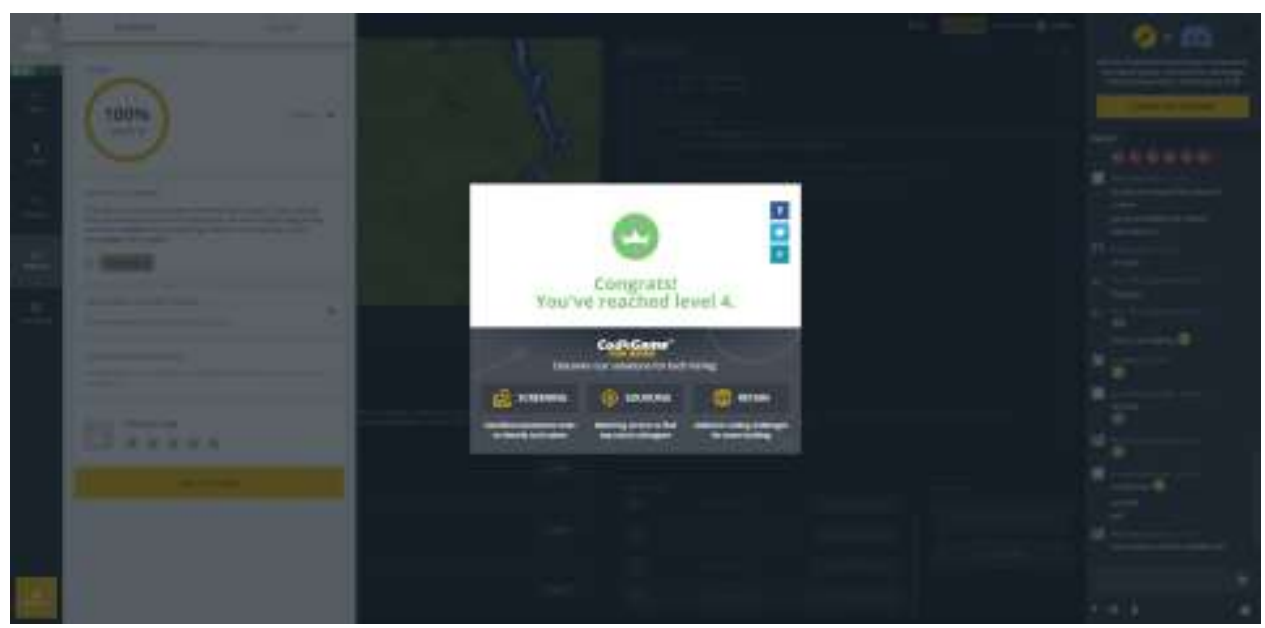

(https://www.codingame.com)

Gambar 13. Tampilan ketika solusi dari tantangan Power of Thor sudah sesuai kriteria

Pengguna yang sudah menyelesaikan sebuah tantangan bisa melanjutkan dengan memilih tantangan yang baru, atau mencoba untuk mengulangi tantangan yang sama.

\section{Hasil evaluasi terhadap pengguna}

Hasil evaluasi yang diperoleh dari pengisian kuesioner oleh 17 mahasiswa ditampilkan pada Gambar 14.

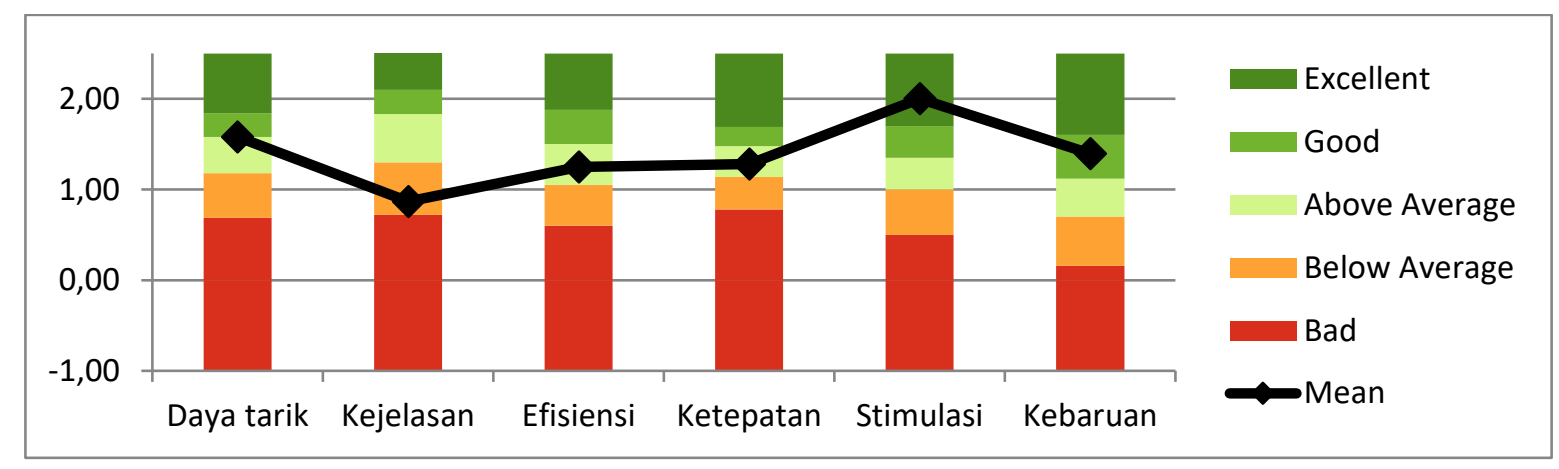

Gambar 14. Diagram benchmark $U E Q$ CodinGame

Berdasarkan diagram hasil benchmark $U E Q$ tersebut, skala stimulasi menempati kategori excellent (sangat baik) yang artinya pengguna merasa tertarik dan termotivasi untuk menggunakan CodinGame. Skala kebaruan menempati kategori good (baik). Skala daya tarik, efisiensi, dan ketepatan menempati kategori above average (di atas rata-rata). Sedangkan skala kejelasan menempati kategori below average (di bawah rata-rata). 
Selanjutnya dilakukan pengumpulan data untuk mengetahui penilaian responden terhadap CodinGame setelah mereka berlatih pemrograman. Hasil penilaian disajikan pada Tabel 2.

Tabel 2. Hasil penilaian responden setelah berlatih di CodinGame

\begin{tabular}{|l|c|c|c|}
\hline \multirow{2}{*}{ Pertanyaan } & \multicolumn{3}{c|}{ Jumlah responden } \\
\cline { 2 - 4 } & Ya & Mungkin & Tidak \\
\hline $\begin{array}{l}\text { Apakah CodinGame bisa dijadikan tempat untuk latihan } \\
\text { pemrograman bagi Perguruan Tinggi? }\end{array}$ & $\begin{array}{c}15 \\
(88,23 \%)\end{array}$ & $\begin{array}{c}2 \\
(11,77 \%)\end{array}$ & 0 \\
\hline $\begin{array}{l}\text { Apakah anda merasa terbantu latihan pemrograman di } \\
\text { CodinGame? }\end{array}$ & 15 & 2 & 0 \\
\hline $\begin{array}{l}\text { Apakah materi latihan di CodinGame lebih baik daripada } \\
\text { materi latihan di kampus anda? }\end{array}$ & 4 & $11,77 \%)$ & \\
\hline $\begin{array}{l}\text { Apakah CodinGame menambah motivasi anda untuk } \\
\text { berlatih koding? }\end{array}$ & $(23,53 \%)$ & $(64,70 \%)$ & $(11,77 \%)$ \\
\hline
\end{tabular}

Berdasarkan hasil penilaian pada Tabel 2, sebanyak 88,23\% responden berpendapat bahwa CodinGame bisa digunakan sebagai tempat latihan pemrograman. Kemudian sebanyak 88,23\% responden merasa terbantu untuk berlatih pemrograman. Selain itu, sebanyak $82,35 \%$ responden merasa lebih termotivasi untuk berlatih pemrograman.

\section{Simpulan}

Setelah melakukan observasi terhadap fitur-fitur yang ada pada CodinGame, peneliti menyimpulkan bahwa platform tersebut cocok digunakan untuk melatih kemampuan pemrograman penggunanya. Hal ini didukung oleh data hasil evaluasi terhadap pengguna. Data hasil evaluasi UEQ menunjukkan bahwa responden merasa tertarik dan termotivasi untuk menggunakan CodinGame, Sedangkan, dari data "hasil penilaian responden setelah berlatih di CodinGame" terlihat bahwa responden merasa terbantu untuk berlatih pemrograman. Kemudian dari data juga terlihat bahwa responden menjadi lebih termotivasi untuk berlatih pemrograman.

\section{Daftar Pustaka}

1. N. Abidin, R. Arsad, N. Muslim, and S. Masrom, "Computer Game Application for JAVA Programming Language Learning," Math. Sci. Informatics J., vol. 1, no. September, pp. 77-89, 2020, [Online]. Available: https://ir.uitm.edu.my/id/eprint/38992/1/38992.pdf.

2. C. C. Hernandez et al., "Teaching Programming Principles through a Game Engine," CLEI Electron. J., vol. 13, no. 2, 2010, doi: 10.19153/cleiej.13.2.3.

3. S. Sylviani, F. C. Permana, and R. G. Utomo, "PHET Simulation sebagai Alat Bantu Siswa Sekolah Dasar dalam Proses Belajar Mengajar Mata Pelajaran Matematika," Edsence J. Pendidik. Multimed., vol. 2, no. 1, pp. 1-10, 2020, doi: 10.17509/edsence.v2i1.25184.

4. S. Sylviani and F. C. Permana, "Dragonbox Algebra 5+ sebagai Media Pembelajaran Aljabar untuk Siswa Sekolah Dasar,” Edsence J. Pendidik. Multimed., vol. 2, no. 2, pp. 75-82, 2020, doi: 10.17509/edsence.v2i2.29928.

5. S. Sylviani and F. C. Permana, "Pembelajaran Matematika Tingkat Sekolah Dasar Menggunakan Aplikasi Geogebra sebagai Alat Bantu Siswa dalam Memahami Materi Geometri," Edsence J. Pendidik. Multimed., vol. 1, no. 1, pp. 1-8, 2019, doi: 10.17509/edsence.v1i1.17909.

6. A. Giannakoulas and S. Xinogalos, "Current trends in on-line games for teaching programming concepts to primary school students," in Communications in Computer and Information Science, 2019, vol. 993, doi: 10.1007/978-3-030-20954-4_5.

7. J. C. Paiva, J. P. Leal, and R. Queirós, "Game-Based Coding Challenges to Foster Programming Practice," in OpenAccess Series in Informatics, 2020, vol. 81, doi: 10.4230/OASIcs.ICPEC.2020.18.

8. H. S. Nwana, "Software agents: An overview," Knowl. Eng. Rev., vol. 11, no. 3, pp. 205-244, 1996, doi: $10.1017 / \mathrm{s} 026988890000789 \mathrm{x}$. 
9. P. Butt, "Students' Perceptions of Game-Based Learning Using CodinGame," no. July 2016, pp. 151-158, 2019. 